\title{
Oligosarcus jacuiensis (Characiformes: Characidae), a new species from the Uruguay and Jacuí River basins, southern Brazil
}

\author{
Naércio Aquino Menezes ${ }^{1}$ and Alexandre Cunha Ribeiro ${ }^{2}$
}

The new species herein described, collected in the Jacuí and Uruguay River basins, Rio Grande do Sul, Brazil, can be distinguished from the already known species of the genus, but Oligosarcus jenynsii, O. perdido, O. acutirostris, O. solitarius and $O$. hepsetus, by the number of perforated lateral line scales. It shares with the first two species the absence of a premaxillary foramen, present in the last three species and differs from $O$. jenynsii by having a smaller orbital diameter and the tip of the pectoral fin failing to reach the pelvic-fin origin, and from $O$. perdido by the presence of more horizontal scale rows around the caudal peduncle.

A espécie nova descrita aqui, coletada nas bacias dos rios Jacuí e Uruguai, Rio Grande do Sul, Brasil, pode ser diferenciada das espécies já conhecidas do gênero, com exceção de Oligosarcus jenynsii, $O$. perdido, $O$. acutirostris, $O$. solitarius e $O$. hepsetus, pelo número de escamas perfuradas ao longo da linha lateral. Compartilha com as duas primeiras espécies a ausência de um forame no premaxilar, presente nas três últimas espécies e difere de $O$. jenynsii por possuir o diâmetro orbital menor e a extremidade da nadadeira peitoral não alcançando a origem da nadadeira pélvica e de $O$. perdido pela presença de mais séries horizontais de escamas ao redor do pedúnculo caudal.

Key words: Freshwater fish, South America, Neotropical, Systematics, Taxonomy.

\section{Introduction}

The characid genus Oligosarcus Günther, 1864 is presently represented by 17 described species (Menezes, 1987; Miquelarena \& Protogino, 1996; Ribeiro et al., 2007) distributed throughout most of South American river basins below $14^{\circ}$ latitude (Menezes, 1988). This wide distribution range includes the Bolivian and Argentinean Andean highlands, the Brazilian crystalline shield, and lowland areas of the Paraná-Paraguay and coastal rivers of southeastern and southern South America, from the Brazilian State of Bahia in the north to Uruguay, in the south.

The species of Oligosarcus have a distribution pattern consisting mostly of allopatric species, except for $O$. robustus Menezes, 1969, O. oligolepis (Steindachner, 1876) and $O$. jenynsii (Günther, 1864) which occur in sympatry along the coastal plains of Rio Grande do Sul and Uruguay. More recent and accurate examination of the Oligosarcus species from the coastal drainages of
Rio Grande do Sul and Uruguay, including specimens of Oligosarcus jenynsii from near its type-locality and neighboring areas revealed that at least one new species has been misidentified as $O$. jenynsii. In this paper, this new species is described.

\section{Material and Methods}

Specimens are from the Museu de Ciências e Tecnologia, Pontifícia Universidade Católica do Rio Grande do Sul (MCP), Museu de Zoologia da Universidade de São Paulo (MZUSP) and Universidade Federal do Rio Grande do Sul (UFRGS). Morphometrics and meristics follow Menezes (1987). Morphometric data were taken with digital calipers and recorded to tenths of a millimeter.

All measurements were made point-to-point. Since the data sets of the samples are non-parametric the differences in meristic and morphometric data were evaluated through the MannWhitney test (BioEstat 5.0, in Ayres et al., 2007). A difference was considered statistically significant when $\mathrm{p} \leq 0.05$.

\footnotetext{
${ }^{1}$ Museu de Zoologia, Universidade de São Paulo, Caixa Postal 42494, 04218-970 São Paulo, SP, Brazil. naercio@usp.br ${ }^{2}$ Departamento de Zoologia, Instituto de Biociências, Universidade Federal de Mato Grosso. Av. Fernando Corrêa da Costa, 2367, 78060900 Cuiabá, MT, Brazil. ribeiro@gmail.com
} 


\section{Results}

\section{Oligosarcus jacuiensis, new species}

Fig. 1-2a

Holotype. MCP 28980, female, 153 mm SL, Brazil, Rio Grande do Sul, Estrela Velha, rio Jacuí, 29¹5’46”S 53¹4’05”W, R. E. Reis, E. H. Pereira \& V. A. Bertaco, 17 Nov 2001.

Paratypes. Brazil, Rio Grande do Sul. MCP 44405, 8, 132-160 mm SL, MZUSP 104604, 4, 128-160 mm SL, collected with holotype; MCP 18876, 6, 178-205 mm SL, rio Uruguay at Marcelino Ramos, $27^{\circ} 18^{\prime}$ S 52 $20^{\circ}$ 'W, E. Filho, V. Schultz, S. Meurer \& P. Iaczinski, 19 Jul 1995; MCP 26979, 13, 92-109 mm SL, Agudo, lake at UHE Dona Francisca, old mouth of lageado do Gringo, rio Jacuí basin, 29²7’10”S 5315’05”W, R. E. Reis, E. H. Pereira \& V. A. Bertaco, 1 Feb 2001; MCP 37930, 4, 151-188 mm SL, Nova Roma, rio das Antas, rio Jacuí basin, 2904’01”S 51²2’48”W, J. D. Latini, V. A. Capatti \& S. Rodrigues, Aug 2004.

Diagnosis. The number of perforated scales on the lateral line (55-65) distinguishes Oligosarcus jacuiensis from O. pintoi (36-40), O. planaltinae (38-40), O. schindleri (45-54), O. argenteus (44-48), O. longirostris (47-51), O. macrolepis (4448), O. menezesi (40-48), O. bolivianus (49-55), O. oligolepis (69-81), O. paranensis (47-54) and $O$. robustus (75-85). There is an overlap in the number of perforated lateral-line scales between Oligosarcus jacuiensis and O. brevioris, but the latter has fewer longitudinal scale rows around the caudal peduncle (17-20) than O. jacuiensis (21-25). Oligosarcus jacuiensis shares with $O$. jenynsii and $O$. perdido the absence of a foramen on the premaxillary (Fig. 2a) and with respect to this character differs from $O$. acutirostris, $O$. solitarius, and $O$. hepsetus with a conspicuous foramen (Fig. 2b). Oligosarcus solitarius can be further distinguished by possessing 18-20 longitudinal scale rows around the caudal peduncle (vs. 21-25 in O. jacuiensis), but the other two species have all the meristic data largely overlapping those of $O$. jacuiensis although $O$. acutirostris has fewer (50-58) and $O$. hepsetus more (60-75) perforated scales on the lateral line than in O. jacuiensis (55-65). The new species is most similar to $O$. jenynsii but can be readily distinguished from this species by having a smaller orbital diameter (21.0-
$24.5 \%$ of the head length $v$ s. $25.0-34.0 \%$ ) and the tip of the pectoral fin not reaching the pelvic-fin origin (vs. tip of the pectoral fin reaching and extending beyond the pelvic-fin origin in O. jenynsii).

Description. Morphometrics in Table 1 and meristics in Table 2. Meristic and morphometric data based on all lots for this species since no statistical differences found among samples studied. Body moderately large, females (92-205 mm SL) slightly larger than males (101-188 mm SL) in available samples. Dorsal body profile convex with a slight depression at occipital region, slightly concave above caudal peduncle; ventral body profile slightly more convex than dorsal, also concave at lower portion of caudal peduncle. Snout conical, larger than orbital diameter; lower jaw slightly shorter that upper jaw and first two caniniform premaxillary teeth accommodated into two small furrows when mouth is fully closed. Maxillary widening gradually towards end, its posterior tip not extending beyond vertical crossing posterior edge of orbit; single row of 22-34 nearly conical maxillary teeth, number of teeth increasing in larger specimens. Premaxillary with one anterior and one posterior caniniform teeth, 3 to 4 nearly conical teeth aligned with caniniform teeth and one conical tooth slightly smaller than caniniform teeth slightly more internal than main tooth row. Dentary bearing an anterior canine, followed by three conical teeth about equally developed and a posterior row of 12-25 nearly conical teeth, increasing in number with an increase in standard length. Ectopterygoid with 10-20 nearly conical teeth. All nearly conical teeth on premaxillary (Fig. 2a), maxillary, dentary and ectopterygoid with vestigial lateral cusps, anterior edge convex and posterior edge concave, their tips pointing backward. Twenty two to 25 gill rakers on epibranchial and ceratobranchial portions of first gill arch.

Dorsal origin closer to caudal fin base than to tip of snout, dorsal-fin rays ii,9 in all specimens, including holotype; posteriormost ray branched. Adipose fin present. Anal-fin rays iv-v,22-28 fin origin at vertical crossing base of last dorsal-fin ray. Anal fin of sexually mature males with bilateral hooks on posterior edge of last unbranched ray and anterior and posterior branches of anterior 9 branched rays. Number of hooks increasing from

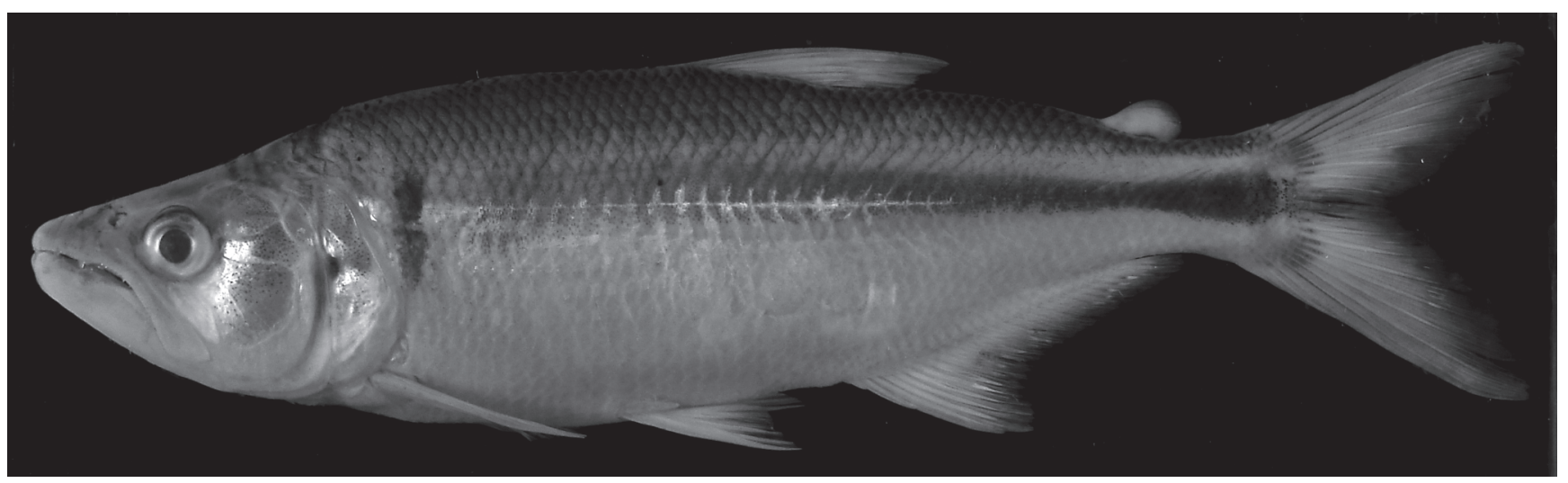

Fig. 1. Oligosarcus jacuiensis, holotype, MCP 28980, female, 153 mm SL, rio Jacuí. 
Table 1. Morphometrics of Oligosarcus jacuiensis, new species (MCP 28980, holotype; MCP 18876, 26979, 37930, 44405; and MZUSP 104604, paratypes). Data of $O$. jenynsii (see comparative material examined) introduced for comparison.

\begin{tabular}{|c|c|c|c|c|c|c|c|c|c|c|}
\hline & \multirow[b]{2}{*}{ Holotype } & \multirow[b]{2}{*}{$\mathrm{n}$} & \multicolumn{2}{|c|}{ Oligosarcus jacuiensis } & \multirow[b]{2}{*}{ SD } & \multicolumn{3}{|c|}{ Oligosarcus jenynsii } & \multirow[b]{2}{*}{ SD } & \multirow[b]{2}{*}{$p$ value } \\
\hline & & & Range & Mean & & $\mathrm{n}$ & Range & Mean & & \\
\hline Standard lenght (mm) & 153.0 & 34 & $92.0-205.0$ & 142.2 & - & 77 & $49.0-165.0$ & 102.4 & - & \\
\hline \multicolumn{11}{|c|}{ Percents of standard lenght } \\
\hline Depth at dorsal-fin origin & 28.7 & 34 & $26.2-30.4$ & 28.1 & 1.1 & 77 & $22.2-31.5$ & 27.6 & 1.7 & 0.243 \\
\hline Snout to dorsal-fin origin & 54.2 & 34 & $53.1-57.8$ & 55.3 & 1.1 & 77 & $52.0-59.7$ & 56.0 & 1.5 & 0.028 \\
\hline Snout to pectoral-fin origin & 29.4 & 34 & 27.3-32.7 & 29.8 & 1.2 & 77 & $26.0-31.7$ & 28.8 & 1.4 & 0.001 \\
\hline Snout to pelvic-fin origin & 49.0 & 34 & $46.2-52.5$ & 49.2 & 1.3 & 76 & $44.3-50.7$ & 47.4 & 1.5 & 0.000 \\
\hline Snout to anal-fin origin & 66.6 & 34 & 64.2-68.6 & 66.8 & 1.0 & 77 & $61.3-70.0$ & 65.2 & 2.0 & 0.000 \\
\hline Caudal peduncle depth & 8.8 & 34 & $8.0-9.6$ & 9.0 & 0.3 & 77 & $8.0-10.0$ & 9.0 & 0.5 & 0.910 \\
\hline Caudal peduncle length & 11.1 & 34 & 11.1-14.8 & 12.5 & 0.8 & 76 & $10.8-14.6$ & 12.4 & 0.8 & 0.825 \\
\hline Pectoral-fin length & 17.6 & 34 & $17.6-22.2$ & 19.3 & 1.1 & 77 & $18.3-23.0$ & 20.4 & 1.1 & 0.000 \\
\hline Pelvic-fin length & 15.7 & 34 & $14.8-17.7$ & 15.7 & 0.8 & 76 & $14.1-18.0$ & 16.2 & 0.8 & 0.014 \\
\hline Dorsal-fin base length & 11.7 & 34 & $10.4-12.3$ & 11.4 & 0.5 & 77 & $10.1-12.8$ & 11.2 & 0.5 & 0.060 \\
\hline Dorsal-fin height & 22.2 & 34 & $20.0-24.3$ & 22.0 & 1.0 & 73 & $21.2-27.8$ & 23.5 & 1.5 & 0.000 \\
\hline Anal-fin base length & 25.5 & 34 & $22.7-27.0$ & 25.1 & 1.1 & 76 & $22.5-28.3$ & 26.1 & 1.1 & 0.000 \\
\hline Anal-fin lobe length & 16.3 & 34 & $14.5-18.2$ & 16.7 & 1.0 & 75 & $15.7-21.8$ & 18.1 & 1.4 & 0.000 \\
\hline Eye to dorsal-fin origin & 39.2 & 34 & $38.6-43.0$ & 40.6 & 0.9 & 77 & $38.5-43.5$ & 41.2 & 1.2 & 0.009 \\
\hline Dorsal-fin origin to caudal-fin base & 48.3 & 34 & $46.1-50.3$ & 47.7 & 1.2 & 77 & $45.2-52.0$ & 47.7 & 1.3 & 0.597 \\
\hline Bony head length & 29.4 & 34 & 28.1-32.3 & 30.0 & 1.2 & 77 & $26.8-32.1$ & 29.0 & 1.3 & 0.001 \\
\hline \multicolumn{11}{|c|}{ Percents of head lenght } \\
\hline Horizontal eye diameter & 22.2 & 34 & $21.0-24.5$ & 23.0 & 1.3 & 77 & $25.0-34.3$ & 28.7 & 2.6 & 0.000 \\
\hline Snout length & 33.3 & 34 & $30.0-34.5$ & 31.4 & 1.4 & 77 & $25.7-32.7$ & 32.7 & 1.5 & 0.000 \\
\hline Least interorbital width & 22.2 & 34 & $20.0-24.4$ & 22.0 & 1.1 & 77 & $18.4-24.4$ & 21.4 & 1.4 & 0.155 \\
\hline Upper jaw length & 60.0 & 34 & 57.1-63.6 & 59.5 & 2.0 & 77 & $51.6-61.8$ & 57.2 & 2.1 & 0.000 \\
\hline
\end{tabular}

anteriormost to about fifth ray and then decreasing towards ninth ray. One specimen (MCP 44405, 142 mm SL) with 9 hooks on last unbranched ray, 16 on fifth, 12 on seventh and 5 on nineth. Moderately developed anterior anal-fin lobe including anterior unbranched rays and first 8 or 9 branched rays. Pectoral-fin rays i, 13-16, tip of longest rays not reaching pelvic-fin origin, far distant from this origin in larger specimens. Pelvic-fin rays i, 7 in all specimens, including holotype; tip of longest rays reaching and extending beyond anus in some large specimens, but never reaching anal-fin origin; mature males with hooks on ventral portion of branched pelvic-fin rays only, increasing from 2 on external branch and 16 on internal branch of first ray to 20 on external branch and 50 on internal branch of fourth ray and then decreasing to 9 on internal branch and 8 on internal branch of seventh ray; hooks on internal branches of pelvic-fin rays always more developed than those on external branches.
Lateral line complete, perforated scales 55-65; 10-12 horizontal scale rows above lateral line, 8-10 below; 21-25 horizontal scale rows around caudal peduncle; 23-29 scales from tip of occipital to dorsal-fin origin; scale row along both sides of anal-fin base extending to about base of $10^{\text {th }}$ or $11^{\text {th }}$ branched anal-fin ray.

Color in alcohol. Body pale yellow darker dorsally due to presence of dark chromatophores, especially concentrated on free edge of scales, lighter ventrally. Dorsal part of head and snout heavily pigmented with dark chromatophores, this pigmentation extending as a narrow stripe over anterior two thirds of maxillary. Lateral head and opercular bones with scattered dark chromatophores. Tip of lower jaw pigmented with dark chromatophores, this pigmentation extending as a narrow stripe along upper lateral portion of lower jaw. Vertically elongate dark blotch at humeral region wider above and gradually narrowing below extending

Table 2. Meristic data of Oligosarcus jacuiensis, new species (MCP 28980, holotype; MCP 18876, 26979, 37930, 44405; and MZUSP 104604, paratypes). Data of $O$. jenynsii (see comparative material examined) introduced for comparison.

\begin{tabular}{|c|c|c|c|c|c|c|c|c|c|c|}
\hline & & \multicolumn{4}{|c|}{ Oligosarcus jacuiensis } & \multicolumn{4}{|c|}{ Oligosarcus jenynsii } & \multirow[b]{2}{*}{$p$ value } \\
\hline & Holotype & $\mathrm{n}$ & Range & Mean & SD & $\mathrm{n}$ & Range & Mean & SD & \\
\hline Branched pectoral-fin rays & 14 & 32 & $13-16$ & 14.0 & 0.8 & 76 & $12-16$ & 13.7 & 0.7 & 0.351 \\
\hline Branched anal-fin rays & 24 & 33 & $22-28$ & 24.8 & 1.7 & 75 & $21-28$ & 24.6 & 1.3 & 0.771 \\
\hline Perforated lateral line scales & 59 & 32 & $55-65$ & 60.3 & 2.4 & 72 & $54-65$ & 59.3 & 2.5 & 0.070 \\
\hline Scales above lateral line & 10 & 32 & $10-12$ & 11.0 & 0.5 & 75 & $10-11$ & 11.0 & 0.3 & 0.297 \\
\hline Scales below lateral line & 9 & 32 & $8-10$ & 9.0 & 0.5 & 72 & 8-9 & 8.6 & 0.5 & 0.012 \\
\hline Predorsal scales & 29 & 33 & $23-29$ & 25.4 & 1.7 & 74 & $22-28$ & 25.0 & 1.5 & 0.247 \\
\hline Scales around caudal peduncle & 23 & 33 & $21-25$ & 23.3 & 1.0 & 67 & $21-25$ & 22.7 & 0.8 & 0.006 \\
\hline Gill rakers & 23 & 33 & $22-25$ & 24.0 & 0.8 & 76 & $23-26$ & 24.2 & 0.7 & 0.029 \\
\hline Premaxillary teeth & 4 & 33 & $3-5$ & 4.0 & 0.4 & 76 & $3-5$ & 4.0 & 0.4 & 1.000 \\
\hline Maxillary teeth & 26 & 33 & $22-34$ & 26.2 & 3.4 & 76 & $19-31$ & 25.1 & 2.4 & 0.245 \\
\hline Posterior dentary teeth & 17 & 33 & $12-25$ & 16.1 & 3.3 & 76 & $12-21$ & 16.0 & 2.0 & 0.812 \\
\hline Ectopterygoid teeth & 13 & 33 & $10-20$ & 13.3 & 2.4 & 70 & $9-18$ & 13.6 & 2.0 & 0.258 \\
\hline
\end{tabular}




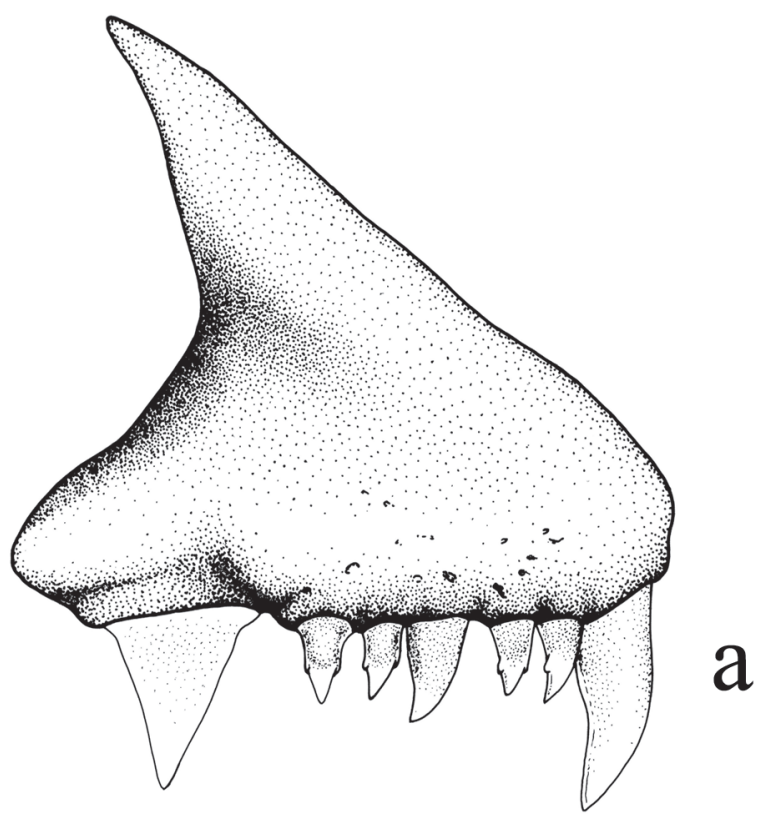

Etymology. The species name jacuiensis is in reference to rio Jacuí in Rio Grande do Sul, Brazil, where most of the specimens were collected. An adjective.

\section{Discussion}

Concerning most of meristic characters, O. jacuiensis is more similar to $O$. jenynsii than to any other species of the genus (Table 2). The $p$ values in bold in the table indicate a significant statistical difference of mean values concerning the number of horizontal scale rows above the lateral line and around the caudal peduncle and the number of gill rakers, but since the ranges corresponding to these characters reveal an almost complete overlap, these differences can be neglected. The two species, however, can be distinguished by the size of the orbital diameter (Fig. 4) and extension of the pectoral fin in relation to pelvic fin origin (see Diagnosis). Table 1 indicates other morphometric differences between the two species ( $p$ values in bold) but when these characters were treated through regression analysis no significant differences were found. The two species are sympatric in the Jacuí and Uruguay River basins.

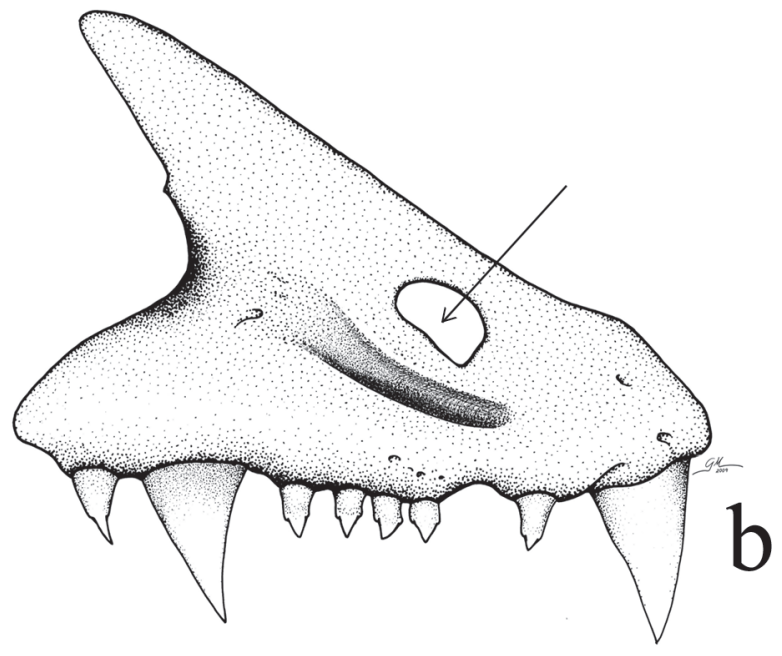

Fig. 2. a) Oligosarcus jacuiensis, new species, MZUSP 104604, $141 \mathrm{~mm}$ SL. b) O. acutirostris, MZUSP 90766, $117 \mathrm{~mm}$ SL. Right lateral view of premaxillae. Black arrow indicates foramen.

ventrally and covering second, third and fourth anterior perforated scales of lateral line. Dark lateral body stripe extending from upper opercle across dark humeral blotch to caudal-fin base, wider and darker on caudal peduncle where it expands dorsally and ventrally and posteriorly extends over median caudal-fin rays. Lateral body stripe narrower anteriorly and over anterior part of caudal peduncle just before expanding dorsally and ventrally, sometimes obscured by guanine and becoming silvery. All fins pale with scattered dark chromatophores especially on dorsal and caudal fins.

Distribution. Known from the Jacuí and Uruguay River basins in Rio Grande do Sul, Brazil (Fig. 3).

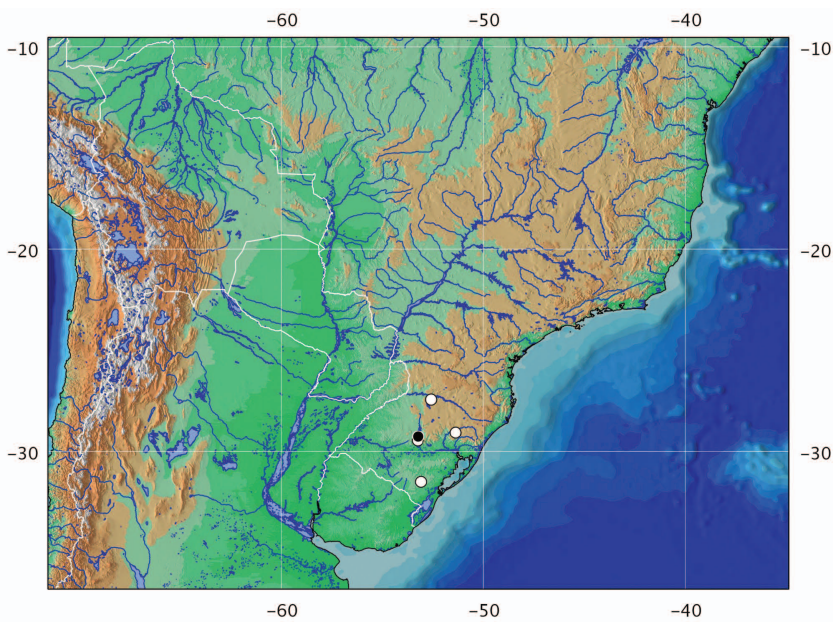

Fig. 3. Map of central and southeastern South America showing the collecting sites (open dots) and the type-locality (black dot) of Oligosarcus jacuiensis.

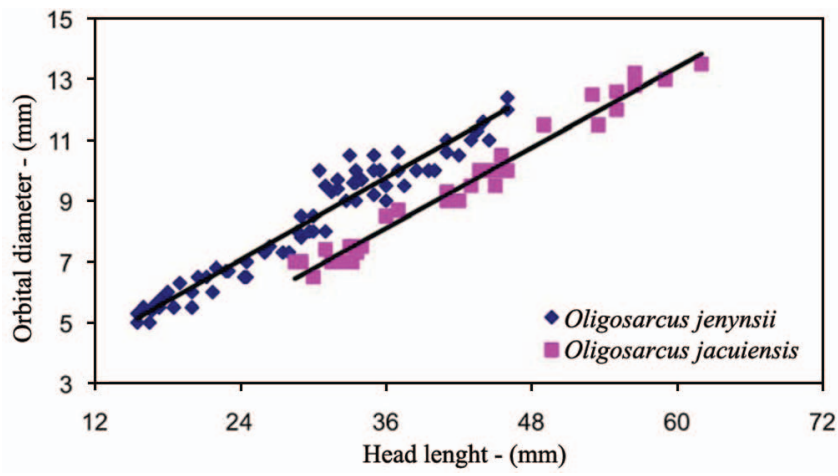

Fig. 4. Orbital diameter as a function of standard length for Oligosarcus jacuiensis, new species, and $O$. jenynsii. 
Comparative material. Oligosarcus acutirostris: Brazil, Espírito Santo, Anchieta - MZUSP 90766, 1, rio Pongal, 2046’32”S 4044’31”W; Oligosarcus jenynsii: Argentina - MZUSP 42369, 42370 and 42371, 3, bacia do Prata, Província de Buenos Aires; MZUSP 42371, 6, Chascomus-Pila, bacia do Prata; Uruguay, Canelones - MCP 37666, 1, southeast of arroyo Tropa Vieja, 34 $32^{\circ}$ 'S 56 $27^{\circ} \mathrm{W}, 34^{\circ} 44^{\prime} 59^{\prime}$ 'S 5550'47'W; MCP 37700, 1, southeast of arroyo Pandó, tributary of río de la Plata, $34^{\circ} 42^{\prime} 12^{\prime}$ 'S 5500'56'47'W, 3444'19”S 5556'27'W; MCP 37696, 2, southeast of arroyo Totoral del Sauce, Ruta 7, km 32.2, tributary of río de La Plata; Tacuarembó - UFRGS 7493, 1, arroyo in Ruta 26, tributary of río Tacuarembó, 3158’39”S 55²4’00”W; UFRGS 7518, 1, arroyo Batovi, Ruta 5, $20 \mathrm{~km}$ from Tacuarembó, tributary of río Tacuarembó, 3154'30”S 5601'04”W; Durazno - UFRGS 7517, 1, tributary of arroyo Mestre de Campo, on road to Polanco de Yi, tributary of río Yi, 3323'S 56²13'18”W; Salto - UFRGS 8018, 2, arroyo San Atonio, $10 \mathrm{~km}$ in Ruta 3, near city of Salto, 31 ${ }^{\circ} 17^{\prime} 14^{\prime \prime} \mathrm{S}$ 5754'34”W; UFRGS 8034, 2, arroyo tributary of río Arapey Grande, in Ruta 4, 3107’44”S 56 59'57’W; UFRGS 8075, 1, arroyo de las Tunas, on Ruta 31, tributary of río Arapey Grande, $31^{\circ} 20^{\prime} 04^{\prime \prime} S$ 57¹9'36”'W; UFRGS 8109, 1 , arroyo on Ruta 4, tributary of arroyo Valentin Grande, 31 $11^{\circ}$ '32”S 5709'22”W; Paysandu - UFRGS 7967, 2, Cañada in Ruta 4, 10 km from Ruta 26, rio Queguay Chico, 3201'57”S 57¹9’30”W; Artigas - UFRGS 8089, 3, arroyo Sarandi, tributary of río Yacuy, 3km from Ruta 3, 3043’59”S 5740’43”W; Brazil, Rio Grande do Sul - MCP 14891, 12, Patos Leste, lagoa Tarumâ near Quintão, 3044’S 50³2’W; MCP 16297, 3, Jacuí, arroyo Pessegueiro in Passo Megatério, 30²8’ 5 533’ W; MCP 25075, 9, São Gonçalo, arroyo on road between Pedro Osório and Basílio, 3153'43”'S 5253'30”W; MCP 11242, 3, Mirim Oeste, mouth of rio Telho with rio Jaguarão, 32 $31^{\circ}$ 'S $53^{\circ} 27^{\prime} \mathrm{W}$; 14355 , 8, lagoa Tarumã (Solidão), 3044’S 50³2'W; MCP 25933, 7, Camaquã, arroyo Hilário on road between Caçapava do Sul and Lavras do Sul, 3046’03”S 5348’23”W; MCP 25964, 2, Camaquã, arroyo Seival on road between Caçapava do Sul and Lavras do Sul, 3044'26”'S 5342’35”W; MCP 33423, 4, Jacuí Quaresma, near rio das Antas, tributary of rio Taquari, $28^{\circ} 52^{\prime} 46^{\prime \prime} \mathrm{S} 51^{\circ} 19^{\prime} 47^{\prime \prime} \mathrm{W}$.

\section{Acknowledgements}

We are grateful to Carlos Alberto S. de Lucena, Zilda Margarete S. de Lucena (MCP) and Luiz R. Malabarba (UFRGS) for making possible the loan of the Oligosarcus specimens examined and for their generous hospitality to one of us (ACR) during stay in Porto Alegre, RS.

\section{Literature Cited}

Ayres, M., M. Ayres Jr., D. L. Ayres \& A. de A. S. Santos 2007. Aplicações estatísticas nas áreas de ciências biomédicas. Belém, Pará: xvii+359p.

Menezes, N. A. 1987. Três espécies novas de Oligosarcus Günther, 1864 e redefinição taxonômica das demais espécies do gênero (Osteichthyes, Teleostei, Characidae). Boletim de Zoologia, Universidade de São Paulo, 11: 1-39.

Menezes, N. A. 1988. Implications of the distribution patterns of the species of Oligosarcus (Teleostei, Characidae) from central and southern South America. Pp. 295-304. In: Hyer, W. R. \& P. E. Vanzolini (Eds.). Proceedings of a workshop on Neotropical distribution patterns. Rio de Janeiro, Academia Brasileira de Ciências, 488p.
Miquelarena, A. M. \& L. C. Protogino. 1996. Uma nueva espécie de Oligosarcus (Teleostei, Characidae) de la cuenca Del Rio Paraná, Misiones, Argentina. Iheringia, Série Zoologia, Porto Alegre, (80): 111-116.

Ribeiro, A. C., M. C. Cavallaro \& O. Froehlich. 2007. Oligosarcus perdido (Characiformes, Characidae), a new species of freshwater fish from Serra de Bodoquena, upper Rio Paraguay basin, Brazil. Zootaxa, 1560: 43-53.

Accepted June 23, 2010

Published September 24, 2010 